\title{
Observations on Natural Foods and Nutrition Content of Critically Endangered Turtle (Leucocephalon yuwonoi) in Central Sulawesi
}

\section{Pengamatan Sumber Pakan Alami Beserta Kandungan Gizinya dari Kura-Kura Berstatus Kritis, Leucocephalon yuwonoi di Sulawesi Tengah}

\author{
Awal Riyanto $^{1 *}$, Wirdateti ${ }^{1}$ dan Suprayogo Soemarno ${ }^{2}$ \\ ${ }^{I}$ Zoology Division, Research Centre for Biology, The Indonesian Institute of Sciences \\ Widyasatwaloka Building, Jl. Raya Jakarta Bogor Km. 46 Cibinong, Indonesia \\ E-mail:awal.riyanto@lipi.go.id and awal_herp@yahoo.com*Penulis untuk korespondensi \\ ${ }^{2}$ Yayasan Kirai Indonesia, Jl. Taman Sari II/58, Karang Tengah, Lebak Bulus, Jakarta, Indonesia
}

\begin{abstract}
Abstrak
Kura-kura Sulawesi (Leucocephalon yuwonoi) adalah satu dari dua jenis kura-kura endemik Sulawesi dengan penyebaran yang terbatas. Sejauh ini data natural historinya sangat minim, padahal sangat dibutuhkan dalam upaya penangkaran satwa yang berstatus kritis IUCN ini. Penelitian ini bertujuan untuk mengungkap tentang pakan di alam beserta kandungan nutrisinya. Survei lapangan dilakukan di kawasan Bangkir dari tanggal 23 Mei sampai 5 Juni 2004 dan di Moutong dari tanggal 11 sampai 19 Oktober 2004. Data pakan di alam diperoleh dari analisis sampel feces dan hasil wawancara kepada para pemburu kurakura beserta pengumpul. Kepastian nama jenis pakan diperoleh dengan melakukan identifikasi sampel tumbuhan pakan di Herbarium Bogoriense. Data kandungan nutrisi diperoleh melalui analisis proksimat sampel pakan yang terkoleksi selama survei. Hasil penelitian ini menunjukkan bahwa terdapat 32 jenis tumbuhan yang jadi sumber pakan di alam, variasi kandungan nutrisi yang cukup besar, kandungan lemak rendah berkisar antara $0.74-8.33 \%(2.41 \pm 2.03)$ dari berat kering. Berdasarkan dominansi, keberadaan di habitat (multiple season) dan tingginya kandungan energi diduga kuat bahwa Colocasia esculenta, Limnocharis flava and Ipomoea aquatica merupakan pakan utama di alam.
\end{abstract}

Kata kunci: Leucocephalon yuwonoi, pakan, nutrisi

Diterima: 16 Juli 2005, disetujui: 13 Maret 2006

\section{Introduction}

As of recently, there are approximately 300 living species of freshwater turtles and tortoises worldwide, of which 38 species occur in Indonesia (Iskandar, 2000); and exported a live to commerciall overseas 18 of these are markets (Yuwono, 1998). There are three species of non-marine chelonian in Sulawesi: two endemic species, the Sulawesia tortoise (Indotestudo forsteni) and the Sulawesi forest turtle (Leucocephalon yuwonoi), and the widespread Malayan box tortoise (Cuora amboniensis), (de Rooij, 1915; McCord et al., 1995). However, the turtles of Sulawesi have received scant scientific attention and little is known about their distribution and life history. Such information is essential for planning effective conservation and resource management strategies (Das, 1997), especially in Sulawesi where remaining wildlife populations are threatened by commercial exploitation and habitat loss (Whitten et al., 1987).

The Sulawesi Forest Turtle was described as Geoemyda yuwonoi (McCord et al., 1995), and later assigned to the new genus Leucocephalon (McCord et al., 2000). The species has featured in the pet trade and Southeast Asian food markets for a number of 
years, but very few natural history sightings? have been reported, and because this species has restricted geographic range and ongoing exploitation exists, Leucocephalon yuwonoi was recently listed as Critically Endangered by the IUCN Red List of Threatened Species (Hilton-Taylor, 2000) and assigned to CITES Appendix II. It has been targeted as a priority species by the recently formed IUCN/SSC Turtle Survival Alliance, and a Taxon Management Group for the species has been established (Innis, 2003). One of the items needed to support a successfull husbandry effort is knowledge about their natural food and nutrition content. So, the objectives of this research are to highlight natural food and nutrition content of the Sulawesi Forest Turtle (Leucocephalon yuwonoi).

\section{Materials and Methods}

The fieldwork was conducted in two habitat localities in Central Sulawesi; "Bangkir River" and "Palembang River" in Bangkir village, Dampal Selatan (Damsel) Subdistrict, Toli-Toli district $\left(0^{0} 15^{\prime} 8.27^{\prime \prime} \mathrm{N} ; 120^{0} 39^{\prime} 4.07^{\prime \prime} \mathrm{E}\right.$; elevation $15-75 \mathrm{~m}$ ) from 23 May until 5 June 2004 and 21 until 26 0ctober 2004; and "Ganonggol River" in desa (village) Karya Agung, Kecamatan (subdistrict) Moutong, Kabupaten (district) Parigi-Moutong $\left(0^{0} 31^{\prime} 5.34\right.$ 'N; 121 ${ }^{0} 02^{\prime} 6.93$ 'E; elevation 25$100 \mathrm{~m})$ from 11-19 October, 2004. Karya Agung is a part of the large transmigration project in Moutong, and the Ganonggol river is characterized by a rocky channel with abundant woody debris and drains an area of second growth forest. Habitat in Bangkir is modified like drainage, small marshes and streams in cacao or coconut plantation areas.

The natural food data was gathered by collecting and analyzing feces, and also by interviewing turtle hunters and the villagers. In cases the samples of plants used for food which could not be identified in the field were collected and then later identified that plants as natural food not identified at localities, it's made specimen feature and than done identified on Herbarium Bogoriense, Indonesia. The parts of plant which become natural food were taken among 500 gram and then were dried by the sun. Herein after to known the nutrition content that includes ash, protein, fat, fiber and gross energy were obtained by proximate analysis following Harris method (1970).

\section{Result and Discussion}

With respect to the variety of natural food countered from both localities that as a whole the food availability on the nature of Leucocephalon yuwonoi shown only $37.5 \%$ is from wild plant (12:32). But when we separated food availability in both localities we found that in the Bangkir area is $30.77 \%$ from wild plant (8:26) and in the Karya Agung area is $61.11 \%$ from wild plant (11:18) (Table 1). This means that Leucocephalon yuwonoi have a wide variety of natural food. As long as this research done, the occurrence of the turtle more even on cultivation areas is more even in Bangkir than in Moutong locality. This is interesting phenomena that the turtle can exist in a cultivation area like in Bangkir. So, the questions are why they can exist and what happens? There are two explanations to answer those questions. The forest in Bangkir is relatively smaller and the rivers, which are connected to the forest and cultivation area, have closed bush riverbank. This condition made the turtle easily migrate to the cultivation area which providing more food. The other explanation, that the villagers in Bangkir are more established than in Moutong that transmigration area so they do not need other income by hunting the turtle. The villagers in Bangkir and buyer said that they have been stop hunting the turtle since 2003. But, this situation truly in endangered because if one times any requests the turtle very easy to capture because until now Leucocephalon yuwonoi not included in protected animal in Indonesia and also no exact information of their presence in conservation area like national parks.

Pursuant to eaten shares as a whole in both localities, shown that leaf is $9.38 \%(3: 32)$; leaf and trunk is $6.25 \%(2: 32)$; fruit is $78.12 \%$ (25:32); and eaten shares of leaf, trunk and 
corm is $6.25 \%$ (2:32). Ipomoea aquatic and Limnocharis flava are consumed in leaf and trunk part. Alocasia macrorhiza and Colocasia esculenta are consumed in leaf, trunk and corm part.

The availability of the fruits depends on season and awaits ruin when ripe; this matter caused the fruits to be eaten by turtles in ripe conditions. For this reason, the multiple season presence of the Ipomoea aquatica, Alocasia macrorrhiza, Limnocharis flava and Colocasia esculenta in both areas are indicated them as main natural food. These is also supported by fact that most all of Alocasia macrorhiza and Colocasia esculenta part like leaf, trunk and corm were consumed; and leaf and trunk of Ipomoea aquatica and Limnocharis flava.

Table 1. The natural foods of Leucocephalon yuwonoi on Bangkir (Dampal Selatan) and Moutong.

\begin{tabular}{|c|c|c|c|c|c|c|c|c|c|}
\hline \multirow[t]{2}{*}{ No } & \multirow[t]{2}{*}{ Species } & \multicolumn{4}{|c|}{ Shares eaten } & \multicolumn{2}{|c|}{ Plant Category } & \multicolumn{2}{|c|}{ Locality } \\
\hline & & leaf & fruit & Trunk & corm & wild & cultivate & Moutong & Bangkir \\
\hline 1 & Alocasia macrorhiza Schoot & + & - & + & + & + & - & - & + \\
\hline 2 & Annona muricata & - & + & - & - & - & + & - & + \\
\hline 3 & Artocarpus elasticus BI. & - & + & - & - & - & + & - & + \\
\hline 4 & Artocarpus integra & - & + & - & - & - & + & + & + \\
\hline 5 & Averrhoa bilimbi Linn & - & + & - & - & - & + & - & + \\
\hline 6 & Cayratia trifolia $(\mathrm{L})$ Domin & - & + & - & - & - & + & + & - \\
\hline 7 & Citrus maxima & - & + & - & - & - & + & - & + \\
\hline 8 & Colocasia esculenta Hook .f. & + & - & + & + & - & + & + & + \\
\hline 9 & Cucumis sativus & - & + & - & - & - & + & - & + \\
\hline 10 & Cucurbita ficifolia & - & + & - & - & - & + & - & + \\
\hline 11 & Desmodium heterocarpum (L.) DC. & + & - & - & - & + & - & + & + \\
\hline 12 & Dillenia sp. & - & + & - & - & + & - & + & - \\
\hline 13 & Diplazium esculentum (Retz.)Sw & + & - & - & - & + & - & + & + \\
\hline 14 & Eugenia subglauca K. \& V. & + & - & - & - & + & - & + & + \\
\hline 15 & Ficus parientalis $\mathrm{Bl}$. & - & + & - & - & + & - & + & - \\
\hline 16 & Ficus septica Burm.f. & - & + & - & - & + & - & + & + \\
\hline 17 & Ficus variegate & - & + & - & - & + & - & + & - \\
\hline 18 & Horsfieldia sp. & - & + & - & - & + & - & + & + \\
\hline 19 & Ipomoea aquatica & + & - & + & - & - & + & - & + \\
\hline 20 & Limnocharis flava (L.)Buchenau & + & - & + & - & + & - & + & + \\
\hline 21 & Litsea sp. & - & + & - & - & + & - & + & - \\
\hline 22 & Mangifera indica Blume & - & + & - & - & - & + & - & + \\
\hline 23 & Monochoria vaginalis & - & + & - & - & - & + & - & + \\
\hline 24 & Musa acuminata Colla & - & + & - & - & - & + & - & + \\
\hline 25 & Musa brachycarpa & - & + & - & - & - & + & - & + \\
\hline 26 & Musa (AAp Group) & - & + & - & - & - & + & - & + \\
\hline 27 & Nauclea sp. & - & + & - & - & - & + & + & - \\
\hline 28 & Pometia pinnata J.R.\& G. Forst & - & + & - & - & + & - & + & + \\
\hline 29 & Psidium guajava Linn & - & + & - & - & - & + & + & + \\
\hline 30 & Sandoricum koetjape Burm.f & - & + & - & - & - & + & + & + \\
\hline 31 & Syzygium sp. & - & + & - & - & - & + & + & + \\
\hline \multirow[t]{2}{*}{32} & Zea mays & - & + & - & - & - & + & - & + \\
\hline & & 7 & 25 & 4 & 2 & 11 & 20 & 18 & 26 \\
\hline
\end{tabular}

According to the Proximate analysis result to some natural food from Bangkir and Moutong areas shows that Leucocephalon yuwonoi has a large variety in nutrition content, e.q: dry materials among $81.26-95.46 \%$; ash 2.18 - 49.51\%; protein $1.92-31.60 \%$; fiber
1.75 - $43.20 \%$; fat $0.74-8.33 \%$; and gross energy 1473-5247 Cal/g (Table 2). According the fat content, we strongly suggest that Leucocephalon yuwonoi needed fat in their food, as their in take level is very low $(2.41+2.03) \%$. 
Table 2. Nutrition content of some natural foods of Leucocephalon yuwonoi from Bangkir (Dampal Selatan) and Moutong, Central Sulawesi.

\begin{tabular}{clcccccc}
\hline \hline \multirow{2}{*}{ No Natural Foods } & \multicolumn{5}{c}{ Nutrition Content (\%) } \\
\cline { 3 - 7 } & DM & Ash & P & F & Ft & GE (Cal/g) \\
\hline \hline 1 & Artocarpus sp. (fruit) & 87.76 & 4.72 & 4.62 & 5.39 & 1.78 & 3650 \\
2 & Cauratia trifolia (fruit) & 93.64 & 4.75 & 10.19 & 34.58 & 8.33 & 5247 \\
3 & Colocasia esculenta (trunk) & 85.69 & 14.30 & 9.06 & 24.42 & 1.49 & 3568 \\
4 & Colocasia esculenta (leaf) & 81.26 & 6.76 & 15.89 & 19.59 & 1.92 & 4226 \\
5 & Colocasia esculenta (corm) & 84.04 & 2.18 & 4.40 & 8.06 & 2.18 & 4213 \\
6 & Desmodium heterocarpum (leaf) & 93.52 & 6.04 & 13.92 & 27.75 & 1.76 & 3889 \\
7 & Diplazium esculentum (leaf) & 89.67 & 10.65 & 31.60 & 10.27 & 1.13 & 4303 \\
8 & Ficus variegata (fruit) & 94.61 & 9.17 & 8.05 & 33.77 & 7.07 & 4060 \\
9 & Syzygium sp. & 90.51 & 4.94 & 6.64 & 41.94 & 1.10 & 3414 \\
10 & Citrus maxima & 83.89 & 4.27 & 5.95 & 6.91 & 1.62 & 3387 \\
11 & Ipomoea aquatica (leaf) & 90.90 & 11.03 & 12.46 & 26.35 & 0.74 & 3480 \\
12 & Cucurbita ficifolia & 92.49 & 7.40 & 9.60 & 30.59 & 1.19 & 3516 \\
13 & Limnocharis flava (trunk) & 95.46 & 15.77 & 1.92 & 23.83 & 3.57 & 3800 \\
14 & Limnocharis flava (leaf) & 82.11 & 7.66 & 17.12 & 20.82 & 1.99 & 3142 \\
15 & Litsea sp. (fruit) & 86.10 & 7.11 & 6.07 & 27.02 & 2.71 & 4187 \\
16 & Diplazium esculentum (leaf) & 94.54 & 49.51 & 11.20 & 14.08 & 1.46 & 1473 \\
17 & Mangifera indica (fruit) & 91.66 & 3.88 & 5.25 & 8.64 & 1.20 & 3636 \\
18 & Musa brachycarpa (fruit) & 91.78 & 7.01 & 7.97 & 34.28 & 1.18 & 3432 \\
19 & Musa (AAp group) (fruit) & 93.92 & 2.22 & 3.70 & 1.75 & 1.29 & 3611 \\
20 & Psidium guajava (fruit) & 93.88 & 2.27 & 4.68 & 43.20 & 4.56 & 3166 \\
\hline \hline
\end{tabular}

Remarks: DM = dry materials; $\mathrm{P}=$ Protein; F = Fiber; Ft = Fat; and GE = Gross Energy.

The highest energy provided by fruit of Cauratia trifolia, then followed by leaf of Diplazium esculentum, leaf of Colocasia esculenta, corn of Colocasia esculenta, fruit of Litsea sp. and fruit of Ficus variegata. Cauratia trifolia seldom is found at the habitat while Diplazium esculentum met many riparian.

As long as observation, in the areas especially in Bangkir most turtle found were predominantly Colocasia esculenta, Limnocharis flava and Ipomoea aquatica. Based on the nutrition content of these plants they have highest gross energy. These facts strongly suggested that Colocasia esculenta, Limnocharis flava and Ipomoea aquatica were the main natural food.

\section{Conclusion}

The Leucocephalon yuwonoi has large variety in their natural food nutrition content with very low fat among $0.74-8.33 \%$ $(2.41 \pm 2.03)$ their dry material. Based on the multiple season presence, highest gross energy content and predominant in the place of turtle found, Colocasia esculenta, Limnocharis flava and Ipomoea aquatica are main natural food.

\section{Acknowledgements}

We wish to express our gratitude to Siti Nuramaliati Prijono (Museum Zoologicum Bogoriense) and Irawati (Bogor Botanical Garden) for their fully supporting this research. We are grateful to Achmad Saim, Mulyadi, Hary Krettiawan, Alek Turendi, Arten, Ramang, Rudi, Abdul Khohar, Fuddin Taula and Sulo for the field assistance in Central Sulawesi. We are also deeply grateful to Ismail (Herbarium Bogoriense) for his help in identifying of plant samples. The research was funded by Indonesian Government via Competitive Program, subprogram IX of Indonesian Institute of Sciences (a grant for domesticated) in 2004.

\section{Literature Cites}

Colijn, E. 2001. IUCN Reptile Red List Indonesia. http://www.nature-conservation.or.id. $\quad 20$ April. 
Das, I. 1997. Conservation problem of tropical Asia's most threatened turtle. In: Van Abbema, J. (Eds.). Proceedings: Conservation, restoration, and management pf tortoises and turtles. New York: New York Turtle and Tortoise Society and WCS Turtle Recovery Program, pp. 295-301.

De Rooij, N. 1915. The Reptiles of the Indo-Australian Archipelogo. Vol.1: Lacertilia, Chelonia, Emydosauria. Leiden.

Harris, L.E. 1970. Nutrition Research Techniques for Domestic and Wild Animals. Animal science Department, Utah State University, Logan.

Hilton-Taylor, C (Compiler). 2000. IUCN Red List of Threatened Species. Gland, Switzerland and Cambridge, UK.

Innis, C. 2003. Preliminary Observations on Reproductive Parameters of the Sulawesi Forest Turtle (Leucocephalon yuwonoi) in Captivity. Chelonian Conservation and Biology 4: 154159.
Iskandar, D.T. 2000. The Indonesian and Papua Turtles and Crocodiles (With notes about species in South East Asia). ITB Press, Bandung.

McCord, W.P., Iverson, J.B. and Boeadi. 1995. A new Batagurid turtle from northern Sulawesi, Indonesia. Chelonian Conservation and Biology 1: 311-316.

McCord, W.P., Iverson, J.B., Spinks, P.Q. and Shafer, H.B. 2000. A new genus of geoemydid turtle from Asia. Hamadryad 25: 86-90.

Yuwono, F.B. 1998. The trade of live animals in Indonesia. In Erdelen, W (Ed). Conservation, Trade and Sustainable Use of Lizards and Snakes in Indonesia. Mertensiella 9: 9-15.

Whitten, A.J., Mustafa, M. and Henderson, G.S. 1987. The Ecology of Sulawesi. Gadjah Mada University Press, Yogyakarta. 